\title{
KAJIAN KOMPARASI PENERAPAN METODE FIS MAMDANI DAN AHP DALAM SISTEM PENDUKUNG KEPUTUSAN SELEKSI GURU TETAP STUDI KASUS: SMK. XYZ
}

\author{
Imam Sunoto \\ Fakultas Teknik Matematika dan IPA, Program Studi Teknik Informatika \\ Universitas Indraprasta PGRI \\ Email: raidersimam@gmail.com
}

\begin{abstract}
ABSTRAK
Guru adalah pendidik profesional yang mempunyai tugas, fungsi, dan peran penting dalam mencerdaskan kehidupan bangsa. Guru yang profesional diharapkan mampu berpartisipasi dalam pembangunan nasional untuk mewujudkan insan Indonesia yang bertakwa kepada Tuhan YME, unggul dalam ilmu pengetahuan dan teknologi, memiliki jiwa estetis, etis, berbudi pekerti luhur, dan berkepribadian. Dalam memenuhi kebutuhan akan guru tetap di lingkungan Sekolah Menengah Kejuruan (SMK) XYZ, maka pihak sekolah mengadakan penyeleksian terhadap guru tidak tetap/ honorer yang telah mengajar cukup lama. Salah satu cara yang dapat dilakukan yaitu dengan menggunakan pendekatan metode Fuzzy Infrence System (FIS) Mamdani dan metode Analytical Hierarchy Process (AHP). Kriteria penilaian dapat dilakukan dengan melihat Kriteria-kriteria yang dipertimbangkan dalam seleksi tersebut, yaitu: kompetensi pedagogik, kompetensi kepribadian, kompetensi professional, dan kompetensi sosial. Dari kriteria tersebut, maka dibuatlah suatu Sistem Pendukung Keputusan (SPK). Kriteria Penentuan seleksi guru tetap tersebut selanjutnya diolah dengan pendekatan metode FIS Mamdani dan metode AHP, sehingga dapat diperoleh dengan tepat dan cepat peringkat-peringkat guru tidak tetap yang untuk selanjutnya dapat diajukan sebagai guru tetap. Hasil dari penelitian ini dapat digunakan kepala sekolah dalam menentukan seleksi guru tetap yang ada di SMK. XYZ secara efektif, efisien, dan objektif.
\end{abstract}

Kata kunci: seleksi guru tetap, sistem pendukung keputusan, fis mamdani, ahp, kriteria.

\begin{abstract}
Teachers are professional educators who have the duty, function, and an important role in educating the nation. Professional teachers are expected to participate in national development to realize the Indonesian people who fear God Almighty, excelling in science and technology, has a soul aesthetic, ethical, noble character, and personality. In fulfilling the need of permanent teachers in the Vocational High School (SMK) XYZ, the school held a screening of the temporary teachers/ honoree who has been teaching long enough. One way to do that is by using Fuzzy method approach Infrence System (FIS) Mamdani and Analytical Hierarchy Process (AHP). The assessment criteria can be done by looking at the criteria considered in the selection, namely: pedagogical competence, personal competence, professional competence and social competence. From these criteria, then made a Decision Support System (DSS). Determination Criteria of selection of permanent teachers are then processed with Mamdani FIS method and AHP, so it can be achieved precisely and quickly ratings of temporary teachers who henceforth be proposed as permanent teachers. The results of this study can be used in determining the selection of the principal permanent teachers in SMK. XYZ effectively, efficiently, and objectively.
\end{abstract}

Keywords: selection of permanent teachers, decision support systems, fis mamdani, ahp, criteria.

\section{PENDAHULUAN}

\subsection{Latar Belakang}

Guru merupakan jabatan atau profesi yang memerlukan keahlian khusus sebagai guru. Pekerjaan ini tidak bisa dilakukan oleh orang yang tidak memiliki keahlian untuk melakukan kegiatan atau pekerjaan sebagai guru. Tugas guru sebagai profesi meliputi mendidik, mengajar, dan melatih. Mendidik berarti meneruskan dan mengembangkan nilai-nilai hidup. Mengajar berarti meneruskan dan mengembangkan ilmu pengetahuan dan teknologi. Sedangkan melatih berarti mengembangkan keterampilan-keterampilan pada siswa. Untuk mewujudkan tujuan pendidikan nasional yaitu visi dan misi sekolah, maka sekolah perlu memilih guru tetap yang memiliki kinerja yang baik untuk dijadikan teladan dalam mengajar. Menetapkan guru tetap dapat mendorong peningkatan mutu pengajaran dan meningkatkan motivasi dan 
profesionalisme guru dalam pelaksanaan tugas, maka kepala sekolah membuat kriteria untuk memilih guru tetap.

Dalam memenuhi kebutuhan akan guru tetap di lingkungan Sekolah Menengah Kejuruan (SMK) XYZ, maka pihak sekolah mengadakan penyeleksian terhadap guru tidak tetap/ honorer yang telah mengajar cukup lama. Salah satu cara yang dapat dilakukan yaitu dengan menggunakan pendekatan logika fuzzy infrence system mamdani. Kriteria penilaian dapat dilakukan dengan melihat Kriteria-kriteria yang dipertimbangkan dalam seleksi tersebut, yaitu: kompetensi pedagogik, kompetensi kepribadian, kompetensi professional, dan kompetensi sosial. Dari kriteria tersebut, maka dibuatlah suatu Sistem Pendukung Keputusan (SPK). Kriteria Penentuan seleksi guru tetap tersebut selanjutnya diolah dengan pendekatan logika fuzzy infrence system mamdani, sehingga dapat diperoleh dengan mudah peringkatperingkat guru tidak tetap yang untuk selanjutnya dapat diajukan sebagai guru tetap. Hasil dari penelitian ini diharapkan kepala sekolah mampu menentukan seleksi guru tetap yang ada di SMK. XYZ secara efektif, efisien, dan objektif.

Adapun penelitian yang relevan dengan kasus dipenelitian ini adalah Antoni Aruan (2014) yang telah berhasil meneliti tentang sistem pendukung keputusan pemilihan asuransi jiwa menggunakan metode fuzzy multi criteria decision making. Penelitian tersebut diatas membuktikan bahwa metode fuzzy ini dapat menghasilkan suatu keputusan yang cepat dan tepat, sehingga dapat menjadi pertimbangan bagi pengambil keputusan (decision maker) dalam mengadakan penyeleksian terhadap alternatif yang ada [1].

\subsection{Rumusan Masalah}

Berdasarkan analisis yang telah dilakukan, maka rumusan masalah yang dibahas dapat dilihat dari kerangka pemikiran dalam gambar 1 di bawah ini.

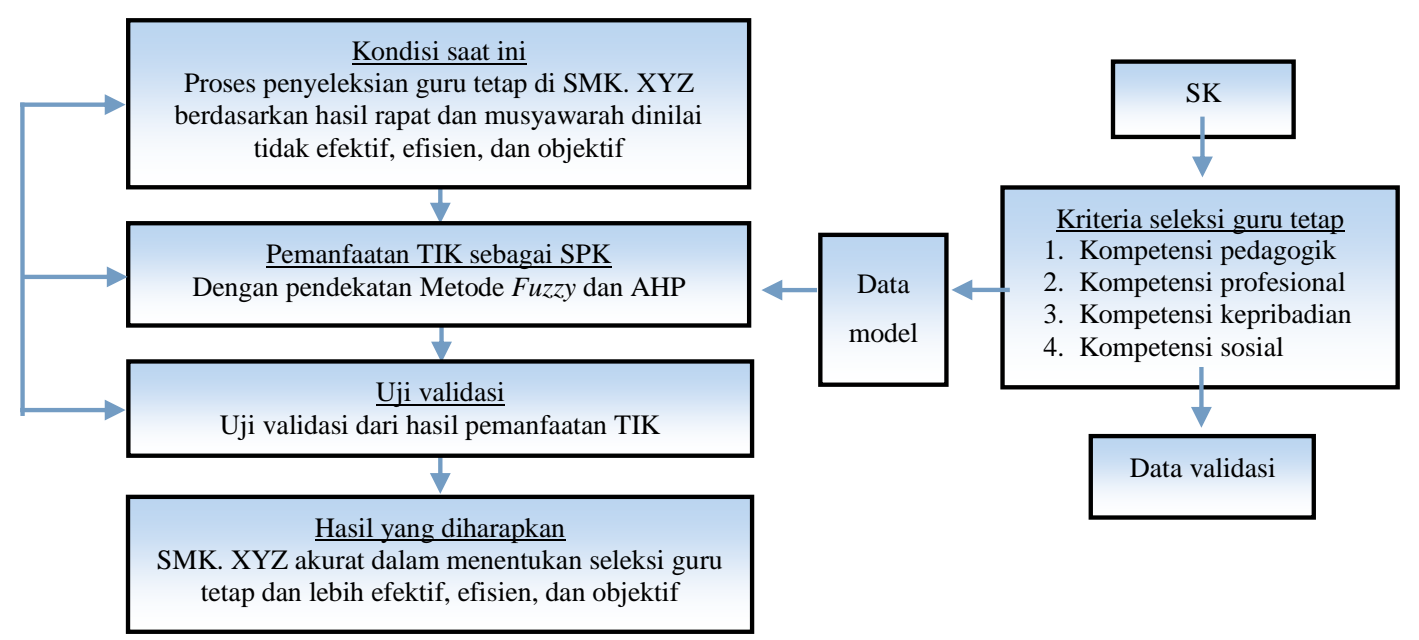

Gambar 1. Kerangka Pemikiran Seleksi Guru Tetap

\subsection{Batasan Masalah}

Berdasarkan rumusan masalah di atas, maka dapat ditetapkan ruang lingkup dan batasan masalah pada penelitian ini yaitu:

1) Perancangan yang dibuat dengan menggunakan penalaran fuzzy dengan menggunakan metode Mamdani dan AHP

2) Variabel kriteria yang digunakan meliputi variabel input yaitu Kompetensi Pedagogik, Kompetensi Profesional, Kompetensi Kepribadian, Kompetensi Sosial, serta variabel output yaitu guru tetap.

3) Pembuatan aturan dalam basis pengetahuan dibantu oleh kepala sekolah.

\section{METODOLOGI PENELITIAN}

\subsection{Pengertian Sistem Pendukung Keputusan}

Sistem adalah suatu kesatuan usaha yang terdiri dari bagian-bagian yang berkaitan satu sama lain yang berusaha mencapai suatu tujuan dalam suatu lingkungan kompleks. Pengertian tersebut mencerminkan adanya beberapa bagian dan hubungan antara bagian, ini menunjukkan kompleksitas dari sistem yang meliputi kerja sama antara bagian yang independent satu sama lain. Selain itu dapat dilihat 
bahwa sistem berusaha mencapai tujuan. Pencapaian tujuan ini menyebabkan timbulnya dinamika, perubahan-perubahan yang terus-menerus perlu dikembangkan dan dikendalikan [2].

Sistem pendukung keputusan sebagai sekumpulan prosedur berbasis model untuk data pemrosesan dan penilaian guna membantu para manajer mengambil keputusan untuk sukses, sistem tersebut haruslah sederhana, cepat, mudah dikontrol, adaptif lengkap dengan isu-isu penting, dan mudah berkomunikasi [3]. Dari definisi tersebut, dapat diindikasikan empat karakteristik utama dari sistem pendukung keputusan, yaitu:

1) Sistem pendukung keputusan menggabungkan data dan model menjadi satu bagian.

2) Sistem pendukung keputusan dirancang untuk membantu para manajer (pengambil keputusan) dalam proses pengambil keputusan dari masalah yang bersifat semi struktural (tidak terstruktur).

3) Sistem pendukung keputusan lebih cenderung dipandang sebagai penunjang penilaian manajer dan sama sekali bukan untuk menggantikannya.

4) Teknik sistem pengambil keputusan dikembangkan untuk meningkatkan efektivitas dari pengambil keputusan.

\subsection{Pengertian Fuzzy Logic}

Sebelum munculnya teori fuzzy logic dikenal sebuah logika tegas (crisp logic) yang memiliki nilai benar dan salah secara tegas. Sebaliknya fuzzy logic adalah Suatu logika yang memiliki nilai kekaburan atau kesamaran (fuzzyness) antara benar dan salah. Dalam teori fuzzy logic suatu nilai bisa bernilai benar dan salah secara bersamaan. Namun berapa besar kebenaran dan kesalahan suatu nilai tergantung pada bobot keanggotaan yang dimilikinya. Orang yang belum mengenal fuzzy logic pasti akan mengira bahwa fuzzy logic adalah suatu yang amat rumit dan tidak menyenangkan. Namun, sekali orang mengenalnya, ia pasti akan sangat tertarik dan akan menjadi pendatang baru untuk ikut serta mempelajarinya. Fuzzy logic dikatakan sebagai logika baru yang lama, sebab ilmu tentang fuzzy logic modern dan metodis baru ditemukan beberapa tahun yang lalu, padahal sebenarnya konsep tentang fuzzy logic itu sendiri sudah ada pada diri kita sejak lama. Fuzzy logic adalah suatu cara yang tepat untuk memetakan suatu ruang Input ke dalam suatu ruang output [4].

\subsection{Logika Fuzzy Infrence System Mamdani}

Logika fuzzy infrence system Mamdani sering juga dikenal dengan nama Metode Max-Min. Metode ini diperkenalkan oleh Ebrahim Mamdani pada tahun 1975 [4]. Untuk mendapatkan Output, diperlukan 4 tahapan:

1) Pembentukan himpunan fuzzy. Menentukan variabel fuzzy dan himpunan fuzzy nya. Kemudian tentukan derajat keanggotaan antara data masukan fuzzy dengan himpunan fuzzy yang telah didefenisikan untuk setiap variabel masukan sistem dari setiap aturan fuzzy.

2) Aplikasi fungsi implikasi pada logika fuzzy infrence system Mamdani. Fungsi implikasi yang digunakan adalah min. Hasil implikasi fuzzy dari setiap aturan ini kemudian digabungkan untuk menghasilkan keluaran infrensi fuzzy.

3) Komposisi Aturan (rule). Tidak seperti penalaran monoton, apabila sistem terdiri dari beberapa aturan, maka infrensi diperoleh dari kumpulan dan korelasi antar aturan. Ada 3 metode yang digunakan dalam melakukan inferensi sistem fuzzy, yaitu: max, additive dan Jumlah babilistik OR.

4) Penegasan (defuzzy). Input dari Proses defuzzifikasi adalah suatu himpunan fuzzy yang diperoleh dari komposisi aturan-aturan fuzzy, sedangkan Output yang dihasilkan merupakan suatu bilangan pada domain himpunan fuzzy tersebut.

Motivasi utama teori fuzzy logic adalah memetakan sebuah ruang Input ke dalam ruang Output dengan menggunakan IF-THEN rule. Pemetaan dilakukan dalam suatu FIS, urutan rule bisa sembarang. FIS mengevaluasi semua rule secara simultan untuk menghasilkan kesimpulan. Oleh karenanya, semua rule harus didefinisikan lebih dahulu sebelum kita membangun sebuah FIS yang akan digunakan untuk menginterpretasikan semua rule tersebut. Mekanisme dalam FIS bisa dirangkum yaitu: FIS adalah sebuah metode yang menginterpretasikan harga-harga dalam vektor Input, menarik kesimpulan berdasarkan sekumpulan IF-THEN rule yang diberikan, dan kemudian menghasilkan vektor Output [5].

\subsection{Analytical Hierarchy Process (AHP)}

Proses Hirarki Analitik untuk mengorganisasikan informasi dan judgment dalam memilih alternatif yang paling disukai [6]. Dengan menggunakan AHP, Suatu persoalan yang akan dipecahkan dalam suatu kerangka berpikir yang terorganisir, sehingga memungkinkan dapat diekspresikan untuk mengambil 
keputusan yang efektif atas persoalan tersebut. Persoalan yang kompleks dapat disederhanakan dan dipercepat proses pengambilan keputusannya.

Prinsip kerja AHP adalah penyederhanaan suatu persoalan kompleks yang tidak terstruktur, strategik dan dan dinamik menjadi bagian-bagiannya, serta menata dalam suatu hirarki. Kemudian tingkat kepentingan setiap variabel diberi nilai numerik secara subjektif tentang arti penting variabel tersebut secara relatif dibandingkan dengan variabel lain. Keuntungan penggunaan AHP, yaitu: kesatuan, kompleksitas, saling ketergantungan, penyusunan hierarki, pengukuran, konsistensi, sintesis, tawarmenawar, penilaian dan konsensus serta pengulangan proses. Dari pertimbangan tersebut kemudian diilakukan sintesa untuk menetapkan variabel yang memiliki prioritas tinggi dan berperan untuk mempengaruhi hasil pada sistem tersebut. Penyusunan skala kepentingan berpedoman pada skala dasar yang terlihat pada tabel 1 di bawah ini.

Tabel 1. Nilai dan definisi pendapat kualitatif dari skala perbandingan Saaty

\begin{tabular}{cl}
\hline Nilai & \multicolumn{1}{c}{ Keterangan } \\
\hline 1 & Faktor vertikal sama penting dengan Faktor horizontal \\
3 & Faktor vertikal lebih penting dengan Faktor horizontal \\
5 & Faktor vertikal jelas lebih penting dengan Faktor horizontal \\
7 & Faktor vertikal sangat jelas lebih penting dengan Faktor horizontal \\
9 & Faktor vertikal mutlak lebih penting dengan Faktor horizontal \\
$2,4,6,8$ & Apabila ragu-ragu antara dua nilai elemen yang berdekatan \\
$1 /(2-9)$ & Kebalikan dari keterangan nilai 2-9 \\
\hline
\end{tabular}

\section{HASIL DAN PEMBAHASAN}

\subsection{Penerapan Logika Fuzzy}

Dalam penyusunan penerapan logika fuzzy infrence system Mamdani untuk menyeleksi guru tetap ini terdapat beberapa langkah yang harus dilakukan untuk mendapatkan data yang valid dalam penyusunannya. Hal tersebut dilakukan untuk mendapatkan hasil berupa guru tetap terbaik dari alternatif yang ada. Menentukan Himpunan Fuzzy berdasarkan Kriteria:

1) Variabel Kompetensi Pedagogik

Kemampuan dalam pengolahan pembelajaran peserta didik yang meliputi; pemahaman wawasan atau landasan kependidikan, pemahaman terhadap peserta didik, pengembangan kurikulum/silabus, perancangan pembelajaran, pemanfaatan teknologi pembelajaran, evaluasi proses dan hasil belajar, pengembangan peserta didik untuk mengaktualisasikan berbagai potensi yang dimilikinya.

2) Variabel Kompetensi Profesional

Sejumlah kompetensi yang berhubungan dengan profesi yang menuntut berbagai keahlian di bidang pendidikan atau keguruan. Kompetensi profesional merupakan kemampuan dasar guru dalam pengetahuan tentang belajar dan tingkah laku manusia, bidang studi yang dibinanya, sikap yang tepat tentang lingkungan KBM dan mempunyai keterampilan dalam teknik mengajar.

3) Variabel Kompetensi Kepribadian

Kompetensi yang berkaitan dengan tingkah laku pribadi guru itu sendiri yang kelak harus memiliki nilai-nilai luhur sehingga terpantul dalam perilaku sehari-hari. Ha ini dengan sendirinya berkaitan erat dengan falsafah hidup yang mengharapkan guru menjadi model manusia yang memiliki nilai-nilai luhur.

4) Variabel Kompetensi Sosial

Kemampuan guru untuk menyesuaikan diri kepada tuntutan kerja di lingkungan sekitar pada waktu membawakan tugasnya sebagai guru. Beberapa kompetensi sosial yang perlu dimiliki guru antara lain; terampil berkomunikasi, bersikap simpatik, dapat bekerja sama dengan Dewan Pendidikan/Komite Sekolah, pandai bergaul dengan kawan sekerja dan mitra pendidikan, dan memahami dunia sekitarnya (lingkungan).

Tabel 2. Pembentuk himpunan fuzzy

\begin{tabular}{cccc}
\hline No & Himpunan & Range & Domain \\
\hline 1 & Buruk & $1-10$ & $0-4$ \\
2 & Cukup & $1-10$ & $3-7$ \\
3 & Baik & $1-10$ & $6-10$ \\
\hline
\end{tabular}


Tabel 2 di atas merupakan variabel semua criteria, dibagi menjadi 3 himpunan fuzzy yaitu: Buruk, Cukup, dan Baik. Himpunan fuzzy Buruk akan memiliki domain [0 - 4] dimana derajat keanggotaan Buruk tertinggi $(=1)$ terletak pada angka 0 - 3. Himpunan fuzzy Cukup memiliki domain [3 - 7] dimana derajat keanggotaan Cukup tertinggi $(=1)$ terletak pada nilai 5. Himpunan fuzzy Baik akan memiliki domain [6 - 10] dimana derajat keanggotaan Baik tertinggi $(=1)$ terletak pada angka $\geq 7$. Variabel semua Kriteria dipresentasikan dengan fungsi keanggotaan bahu dan segitiga. Hasil pengolahan himpunan dapat terlihat seperti pada gambar 2 di bawah ini.

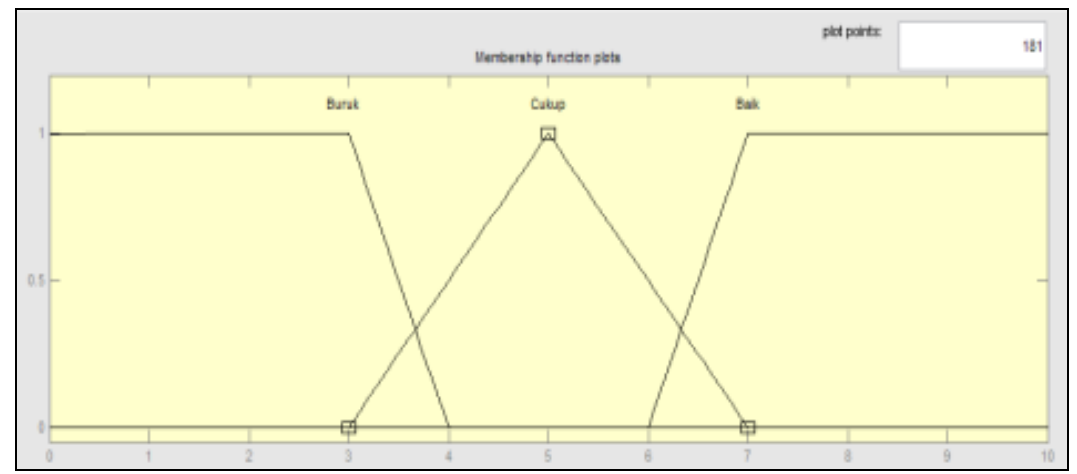

Gambar 2. Grafik Variabel Kriteria

Dan persamaannya.

$\begin{array}{ll}\mu \text { Buruk[x] } & = \begin{cases}1 & ; 0 \leq x \leq 3 \\ (4-x) /(4-3) & ; 3 \leq x \leq 4 \\ 0 & ;\end{cases} \\ \mu \text { Cukup[x] } & = \begin{cases}(x-3) /(4-3) & ; 3 \leq x \leq 4 \\ (7-x) /(4-3) & ; 4 \leq x \leq 7 \\ 0 & ; x \leq 3 \operatorname{atau~} x \geq 7\end{cases} \\ \mu \text { Baik }[\mathrm{x}] & = \begin{cases}0 & ; x \leq 6 \\ (x-6) /(10-6) & ; 6 \leq x \leq 7 \\ 1 & ; 7 \leq x \leq 10\end{cases} \end{array}$

\subsection{Proses Mamdani}

Dalam proses mamdani terdapat beberapa tahapan yang harus dilakukan diantaranya:

\subsubsection{Fuzzifikasi}

Fungsi derajat keanggotaan yang digunakan adalah fungsi linier turun, fungsi segitiga dan fungsi linier naik. Berikut adalah Fungsi Derajat Keanggotaan dari semua variabel:

- Peda1 $($ HFT=1)
- Peda2 $($ HFT=0,66)
- Peda3 $($ HFT $=1)$
- Peda4 $($ HFT $=0,73)$
- Peda5 $($ HFT $=0,71)$
- Peda6 $($ HFT $=0,66)$
- Kep1 $($ HFT=1
- Kep2 $($ HFT $=1)$
- Kep3 $($ HFT $=0,75)$

- Pro1 (HFT=1)

- Pro2 $(\mathrm{HFN}=0,66)$

$(\mathrm{HFT}=0,20)$

- Pro3 $(\mathrm{HFN}=1)$

- Sos1 (HFT=1)

- Sos $2(\mathrm{HFT}=1)$

*Ket: HFT (Himpunan Fuzzy Tinggi) HFN (Himpunan Fuzzy Normal)

\subsubsection{Rules}

Pembentukan rule editor, yaitu tempat dimana rule-rule dikelola, baik itu untuk menambah, menghapus, dan juga mengubah rule. Pada rule editor lah rule dikelola agar nantinya sistem dapat menghasilkan Output sesuai dengan yang Input yang dilakukan pada variabel-variabel Input. Rule yang telah ditetapkan memiliki 22 Rule, sebagai berikut: 
[R1] If Peda1 Baik And Peda2 Baik And Peda3 Baik And Peda4 Baik And Peda5 Baik And Peda6 Baik And Peda7 Baik And Pro1 Baik And Pro2 Baik And Kep1 Baik And Kep2 Baik And Kep3 Baik And Sos1 Baik And Sos2 Baik Then Out Baik.

[R2] If Peda1 Baik And Peda2 Baik And Peda3 Baik And Peda4 Baik And Peda5 Baik And Peda6 Baik And Peda7 Baik And Pro1 Cukup And Pro2 Cukup And Kep1 Cukup And Kep2 Cukup And Kep3 Cukup And Sos1 Cukup And Sos2 Cukup Then Out Baik.

[R3] If Peda1 Baik And Peda2 Baik And Peda3 Baik And Peda4 Baik And Peda5 Baik And Peda6 Baik And Peda7 Baik And Pro1 Buruk And Pro2 Buruk And Kep1 Buruk And Kep2 Buruk And Kep3 Buruk And Sos1 Buruk And Sos2 Buruk Then Out Cukup

[R4] If Peda1 Cukup And Peda2 Cukup And Peda3 Cukup And Peda4 Cukup And Peda5 Cukup And Peda6 Cukup And Peda7 Cukup And Pro1 Buruk And Pro2 Buruk And Kep1 Buruk And Kep2 Buruk And Kep3 Buruk And Sos1 Buruk And Sos2 Buruk Then Out Buruk

[R5] If Peda1 Cukup And Peda2 Cukup And Peda3 Cukup And Peda4 Cukup And Peda5 Cukup And Peda6 Cukup And Peda7 Cukup And Pro1 Baik And Pro2 Baik And Kep1 Baik And Kep2 Baik And Kep3 Baik And Sos1 Baik And Sos2 Baik Then Out Baik

[R6] If Peda1 Cukup And Peda2 Cukup And Peda3 Cukup And Peda4 Cukup And Peda5 Cukup And Peda6 Cukup And Peda7 Cukup And Pro1 Cukup And Pro2 Cukup And Kep1 Cukup And Kep2 Cukup And Kep3 Cukup And Sos1 Cukup And Sos2 Cukup Then Out Cukup

[R7] If Peda1 Buruk And Peda2 Buruk And Peda3 Buruk And Peda4 Buruk And Peda5 Buruk And Peda6 Buruk And Peda7 Buruk And Pro1 Buruk And Pro2 Buruk And Kep1 Buruk And Kep2 Buruk And Kep3 Buruk And Sos1 Buruk And Sos2 Buruk Then Out Buruk

[R8] If Peda1 Baik And Peda2 Baik And Peda3 Baik And Peda4 Baik And Peda5 Baik And Peda6 Baik And Peda7 Baik And Pro1 Cukup And Pro2 Cukup And Kep1 Cukup And Kep2 Cukup And Kep3 Cukup And Sos1 Cukup And Sos2 Cukup Then Out Buruk

[R9] If Peda1 Buruk And Peda2 Buruk And Peda3 Buruk And Peda4 Buruk And Peda5 Buruk And Peda6 Buruk And Peda7 Buruk And Pro1 Baik And Pro2 Baik And Kep1 Baik And Kep2 Baik And Kep3 Baik And Sos1 Baik And Sos2 Baik Then Out Cukup

[R10] If Peda1 Baik And Peda2 Baik And Peda3 Buruk And Peda4 Buruk And Peda5 Cukup And Peda6 Cukup And Peda7 Baik And Pro1 Baik And Pro2 Buruk And Kep1 Buruk And Kep2 Cukup And Kep3 Cukup And Sos1 Baik And Sos2 Baik Then Out Cukup

[R11] If Peda1 Baik And Peda2 Baik And Peda3 Cukup And Peda4 Cukup And Peda5 Buruk And Peda6 Buruk And Peda7 Baik And Pro1 Baik And Pro2 Cukup And Kep1 Cukup And Kep2 Buruk And Kep3 Buruk And Sos1 Baik And Sos2 Baik Then Out Cukup

[R12] If Peda1 Cukup And Peda2 Cukup And Peda3 Buruk And Peda4 Buruk And Peda5 Baik And Peda6 Baik And Peda7 Cukup And Pro1 Cukup And Pro2 Buruk And Kep1 Buruk And Kep2 Baik And Kep3 Baik And Sos1 Cukup And Sos2 Cukup Then Out Cukup

[R13] If Peda1 Cukup And Peda2 Cukup And Peda3 Baik And Peda4 Baik And Peda5 Buruk And Peda6 Buruk And Peda7 Cukup And Pro1 Cukup And Pro2 Baik And Kep1 Baik And Kep2 Buruk And Kep3 Buruk And Sos1 Cukup And Sos2 Cukup Then Out Cukup

[R14] If Peda1 Buruk And Peda2 Buruk And Peda3 Cukup And Peda4 Cukup And Peda5 Baik And Peda6 Baik And Peda7 Buruk And Pro1 Buruk And Pro2 Cukup And Kep1 Cukup And Kep2 Baik And Kep3 Baik And Sos1 Buruk And Sos2 Buruk Then Out Buruk

[R15] If Peda1 Buruk And Peda2 Buruk And Peda3 Baik And Peda4 Baik And Peda5 Cukup And Peda6 Cukup And Peda7 Buruk And Pro1 Buruk And Pro2 Baik And Kep1 Baik And Kep2 Cukup And Kep3 Cukup And Sos1 Buruk And Sos2 Buruk Then Out Buruk

[R16] If Peda1 Baik And Peda2 Baik And Peda3 Baik And Peda4 Cukup And Peda5 Cukup And Peda6 Cukup And Peda7 Buruk And Pro1 Buruk And Pro2 Buruk And Kep1 Baik And Kep2 Baik And Kep3 Baik And Sos1 Cukup And Sos2 Cukup Then Out Baik

[R17] If Peda1 Baik And Peda2 Baik And Peda3 Baik And Peda4 Buruk And Peda5 Buruk And Peda6 Buruk And Peda7 Cukup And Pro1 Cukup And Pro2 Cukup And Kep1 Baik And Kep2 Baik And Kep3 Baik And Sos1 Buruk And Sos2 Buruk Then Out Buruk

[R18] If Peda1 Cukup And Peda2 Cukup And Peda3 Cukup And Peda4 Baik And Peda5 Baik And Peda6 Baik And Peda7 Buruk And Pro1 Buruk And Pro2 Buruk And Kep1 Cukup And Kep2 Cukup And Kep3 Cukup And Sos1 Baik And Sos2 Baik Then Out Baik

[R19] If Peda1 Cukup And Peda2 Cukup And Peda3 Cukup And Peda4 Buruk And Peda5 Buruk And Peda6 Buruk And Peda7 Baik And Pro1 Baik And Pro2 Baik And Kep1 Cukup And Kep2 Cukup And Kep3 Cukup And Sos1 Buruk And Sos2 Buruk Then Out Buruk 
[R20] If Peda1 Buruk And Peda2 Buruk And Peda3 Buruk And Peda4 Baik And Peda5 Baik And Peda6 Baik And Peda7 Cukup And Pro1 Cukup And Pro2 Cukup And Kep1 Buruk And Kep2 Buruk And Kep3 Buruk And Sos1 Baik And Sos2 Baik Then Out Buruk

[R21] If Peda1 Buruk And Peda2 Buruk And Peda3 Buruk And Peda4 Cukup And Peda5 Cukup And Peda6 Cukup And Peda7 Baik And Pro1 Baik And Pro2 Baik And Kep1 Buruk And Kep2 Buruk And Kep3 Buruk And Sos1 Cukup And Sos2 Cukup Then Out Buruk

[R22] If Peda1 Baik And Peda2 Buruk And Peda3 Cukup And Peda4 Baik And Peda5 Buruk And Peda6 Cukup And Peda7 Baik And Pro1 Buruik And Pro2 Cukup And Kep1 Baik And Kep2 Buruk And Kep3 Cukup And Sos1 Baik And Sos2 Buruk Then Out Baik

\subsubsection{Fungsi Implikasi} rule 22 .

Fungsi implikasi yang digunakan adalah metode min dan rule yang terpengaruh adalah rule 21 dan

$$
\begin{aligned}
\alpha_{21} \quad & \min \{\mu \mathrm{t}(12), \mu \mathrm{t}(12), \mu \mathrm{t}(8), \mu \mathrm{t}(22), \mu \mathrm{t}(14), \mu \mathrm{t}(12), \mu \mathrm{t}(10), \mu \mathrm{t}(6), \mu \mathrm{t}(12), \mu \mathrm{t}(10), \mu \mathrm{t}(10), \\
& \quad \mu \mathrm{t}(16), \mu \mathrm{t}(6), \mu \mathrm{t}(6)\} \\
= & \min (1 ; 0,66 ; 1 ; 0,73 ; 0,71 ; 0,66 ; 0,66 ; 1 ; 1 ; 0,75 ; 1 ; 1 ; 1 ; 1) \\
= & 0,66
\end{aligned}
$$

Berdasarkan fungsi keanggotaan dari Variabel Output himpunan tinggi, pada saat $\alpha_{21}=0,66$ diperoleh nilai:

$$
\begin{aligned}
& \mu \mathrm{b} \quad=\left(\mathrm{d}_{21}\right)=\alpha_{21} \quad \longleftrightarrow \frac{\mathrm{d}[21]-\mathrm{a}}{7} \quad=0,66 \\
& \mathrm{~d}[21]=4,62+3 \quad=7,62 \\
& \alpha_{22}=\min \{\mu \mathrm{t}(12), \mu \mathrm{t}(12), \mu \mathrm{t}(8), \mu \mathrm{t}(22), \mu \mathrm{t}(14), \mu \mathrm{t}(12), \mu \mathrm{t}(10), \mu \mathrm{t}(6), \mu \mathrm{t}(12), \mu \mathrm{t}(10), \mu \mathrm{t}(10), \\
& \mu \mathrm{t}(16), \mu \mathrm{t}(6), \mu \mathrm{t}(6)\} \\
& =\min (1 ; 0,66 ; 1 ; 0,73 ; 0,71 ; 0,66 ; 0,2 ; 1 ; 1 ; 0,75 ; 1 ; 1 ; 1 ; 1) \\
& =0,2
\end{aligned}
$$
nilai:

Berdasarkan fungsi keanggotaan variabel Output himpunan tinggi, pada saat $\alpha 22=0,2$ diperoleh

$$
\begin{aligned}
& \mu \mathrm{b}=\left(\mathrm{d}_{22}\right)=\alpha_{22} \quad \longleftrightarrow \frac{\mathrm{d}[22]-3}{7} \quad=0,2 \\
& \mathrm{~d}[22]=1,4+3 \quad=4,4
\end{aligned}
$$

\subsubsection{Komposisi Aturan}

Metode Max digunakan untuk mentukan komposisi aturan.
a) Variabel Output
b) Derajat kebenaran himpunan BAIK
$=\operatorname{Max}\left(\alpha_{21} ; \alpha_{22}\right)$
$=\operatorname{Max}(0,66 ; 0,2)$$$
=0,66
$$

Daerah hasil inferensi tertinggi adalah 0,66 dan terendah 0,2

\subsubsection{Defuzzyfikasi}

Metode yang digunakan untuk fuzzyfikasi adalah centroid.

$$
\begin{aligned}
\mu(\mathrm{x}) & = \begin{cases}0,2 & ; 4,4 \leq d_{21} \leq 7,62 \\
0,66 & ; 7,62 \leq d_{21} \leq 10\end{cases} \\
\mathrm{M} 1 \quad & =\int_{4,4}^{7,62}(0,2) x d x \\
& =0,\left.1 \mathrm{x}^{2}\right|_{4,4} ^{7,62}=5,81-1,9=3,91 \\
\mathrm{M} 2 \quad & =\int_{7_{i}, 62}^{10}(0,66) x d x \\
\text { L1 } & =0,\left.33 \mathrm{x}^{2}\right|_{7_{i}, 62} ^{10}=33-19=14 \\
& =0,2 \quad(7,62-4,4)=0,6
\end{aligned}
$$


L2 $=0,66(10-7,62)=1,5$

Nilai crisp output dihitung dengan:

$\mathrm{Z}^{*}=\frac{M_{1}+M_{2}}{A_{1}+A_{2}}=\frac{14+2,91}{0,6+1,5}=8,53$

Guru tidak tetap yang akan diterima menjadi guru tetap adalah yang memiliki nilai output kompetensi tertinggi setelah melalui hasil pengolahan dengan pendekatan metode fuzzy.

\subsection{Implementasi Program}

Pembuatan prototyping yang merupakan bagian dari produk yang mengekspresikan logika maupun fisik antarmuka eksternal yang ditampilkan [7]. Tampilan Graphic User Interface (GUI) yang merupakan tampilan hasil eksekusi program dan tempat memasukkan nilai pada tiap-tiap variabel Input. Tampilan GUI menggunakan metode fuzzy dapat dilihat pada gambar 3, pada GUI tersebut dapat dilihat hasil atau output dari program.

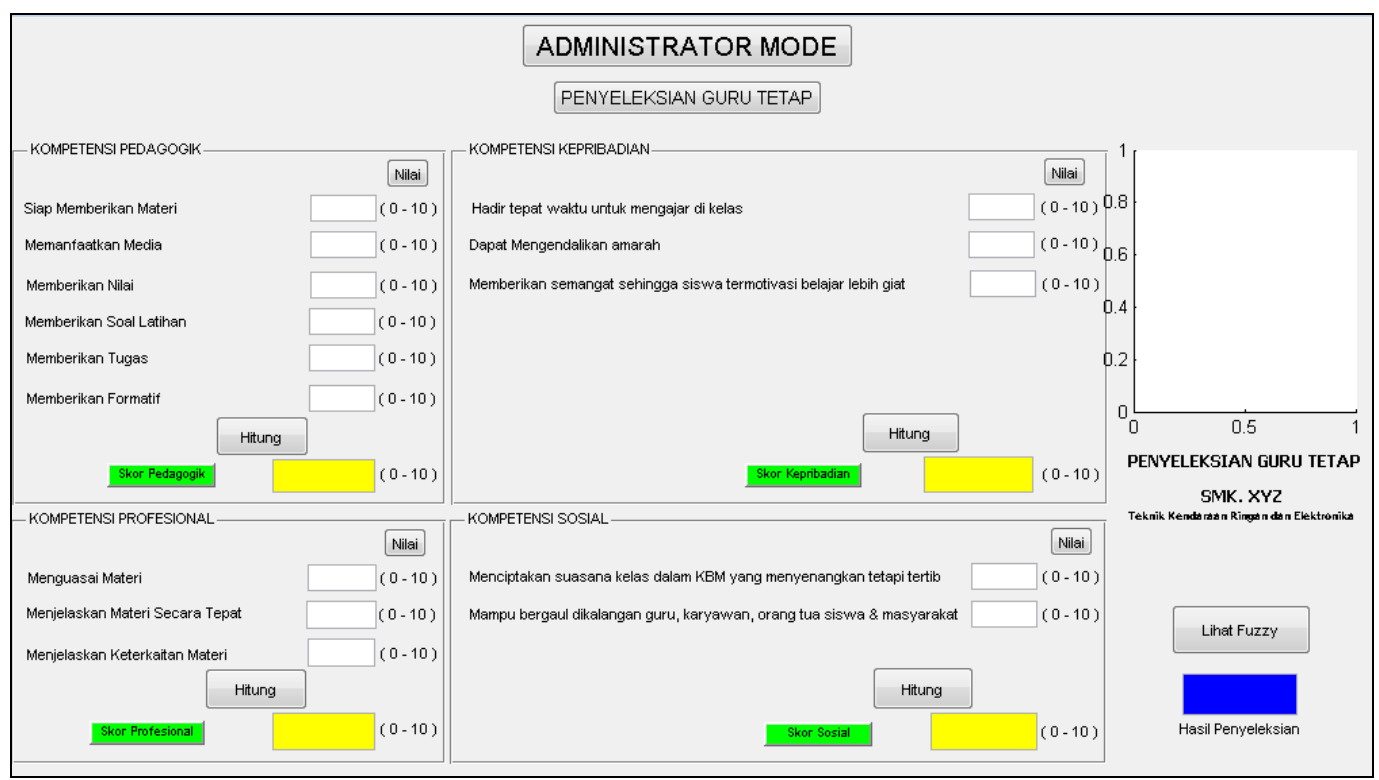

Gambar 3. Graphic User Interface

\subsection{Penerapan Metode AHP}

Dalam prosesnya diperlukan kriteria-kriteria yang akan dijadikan bahan perhitungan pada proses seleksi guru tetap. Kriteria yang menjadi bahan pertimbangan dapat terlihat pada tabel 3 di bawah ini.

Tabel 3. Kriteria

\begin{tabular}{|c|c|}
\hline Kriteria & Keterangan \\
\hline Kompetensi Pedagogik & Kemampuan dalam pengolahan pembelajaran peserta didik \\
\hline Kompetensi Profesonal & $\begin{array}{l}\text { Sejumlah kompetensi yang berhubungan dengan profesi yang } \\
\text { menuntut berbagai keahlian di bidang pendidikan atau keguruan }\end{array}$ \\
\hline Kompetensi Kepribadian & $\begin{array}{l}\text { Kompetensi yang berkaitan dengan tingkah laku pribadi guru itu } \\
\text { sendiri yang kelak harus memiliki nilai-nilai luhur sehingga terpantul } \\
\text { dalam perilaku sehari-hari. }\end{array}$ \\
\hline Kompetensi Sosial & $\begin{array}{l}\text { Kemampuan guru untuk menyesuaikan diri kepada tuntutan kerja di } \\
\text { lingkungan sekitar pada waktu membawakan tugasnya sebagai guru }\end{array}$ \\
\hline
\end{tabular}

Menentukan tujuan yang ingin dicapai dan menentukan kriteria-kriteria untuk seleksi. Nilai terbesar akan terpilih menjadi alternatif dengan nilai tertinggi terpilih sebagai alternatif terbaik. Untuk seleksi guru tetap juga dilakukan proses perengkingan. Menyusun hirarki dari permasalahan yang akan diselesaikan, diuraikan menjadi unsur-unsurnya, yaitu kriteria dan alternatif, kemudian disusun menjadi struktur hierarki seperti gambar 4 di bawah ini. 


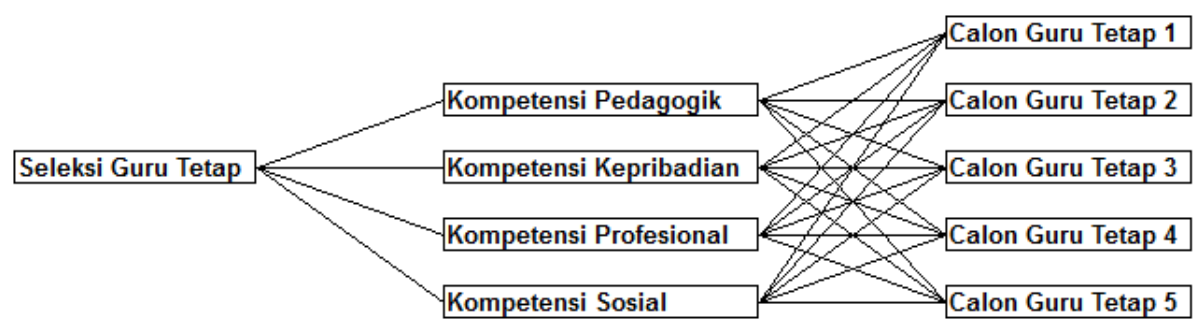

Gambar 4. Sistem Hieraki Seleksi Guru Tetap

Langkah-langkah yang dilakukan untuk seleksi pemilihan guru tetap adalah menentukan prioritas Kriteria, yakni membuat matriks perbandingan berpasangan. Pada tahap ini dilakukan penilaian perbandingan antara satu kriteria dengan kriteria lainnya, seperti terlihat pada tabel 4 berikut ini.

Tabel 4. Matriks seleksi guru tetap

\begin{tabular}{ccccc}
\hline Level & $\sum$ Matriks & Dimensi & $\sum$ Sel & $\sum$ Matriks \\
\hline Goal & 0 & - & - & - \\
Kriteria & 1 & $4 \times 4$ & $1(4 \times 4)=16$ & $1(4 \times 4-4) / 2=6$ \\
Alternatif & 5 & $5 \times 5$ & $5(5 \times 5)=125$ & $5(5 \times 5-5) / 2=50$ \\
& Total Pertanyaan & & $6+50=56$ \\
\hline
\end{tabular}

Penggunaan proses hierarki analitik dengan membandingkan tingkat kepentingan elemen berdasarkan kriteria dapat terlihat pada tabel 5 di bawah ini.

Tabel 5. Pair comparation kriteria

\begin{tabular}{lcccc}
\hline \multicolumn{1}{c}{ Kriteria } & $\begin{array}{c}\text { Kompetensi } \\
\text { Pedagogik }\end{array}$ & $\begin{array}{c}\text { Kompetensi } \\
\text { Profesional }\end{array}$ & $\begin{array}{c}\text { Kompetensi } \\
\text { Kepribadian }\end{array}$ & $\begin{array}{c}\text { Kompetensi } \\
\text { Sosial }\end{array}$ \\
\hline Kompetensi Pedagogik & 1 & 5 & 6 & 5 \\
Kompetensi Profesional & $1 / 5$ & 1 & 3 & 4 \\
Kompetensi Kepribadian & $1 / 6$ & $1 / 3$ & 1 & 4 \\
Kompetensi Sosial & $1 / 5$ & $1 / 4$ & $1 / 4$ & 1 \\
\hline
\end{tabular}

Untuk menentukan prioritas digunakan metode perbandingan berpasangan (Pairwise Comparason) dengan 9 skala penilaian untuk setiap kriteria maupun setiap alternatif berdasarkan criteria. Penggunaan metode perbandingan dapat terlihat pada gambar 5 di bawah ini.

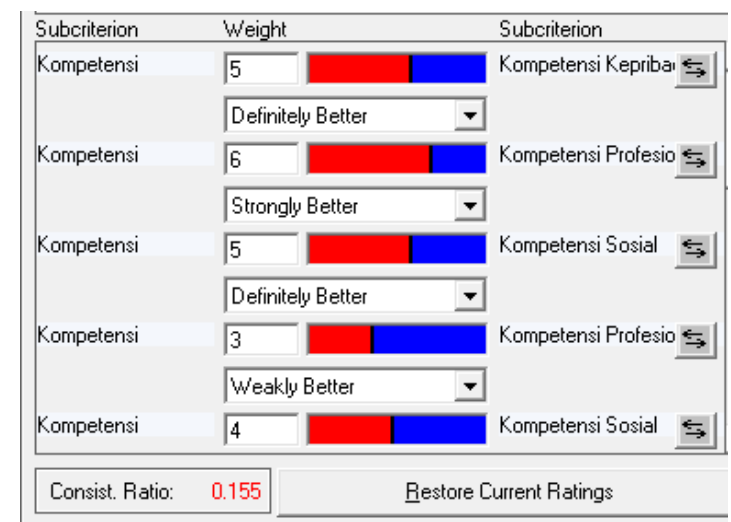

\section{Gambar 5. Perbandingan Tingkat Kepentingan Elemen Faktor}

Pada gambar 6 di bawah ini merupakan hasil skor keputusan penyeleksian, menunjukkan bahwa urutan alternatif guru yang dapat dipertimbangkan menjadi guru tetap yang paling diprioritaskan dari kompetensi yang dimiliki adalah kompetensi pedagogik, kompetensi profesional, kompetensi sosial, dan yang paling sedikit pengaruhnya adalah kompetensi kepribadian. 


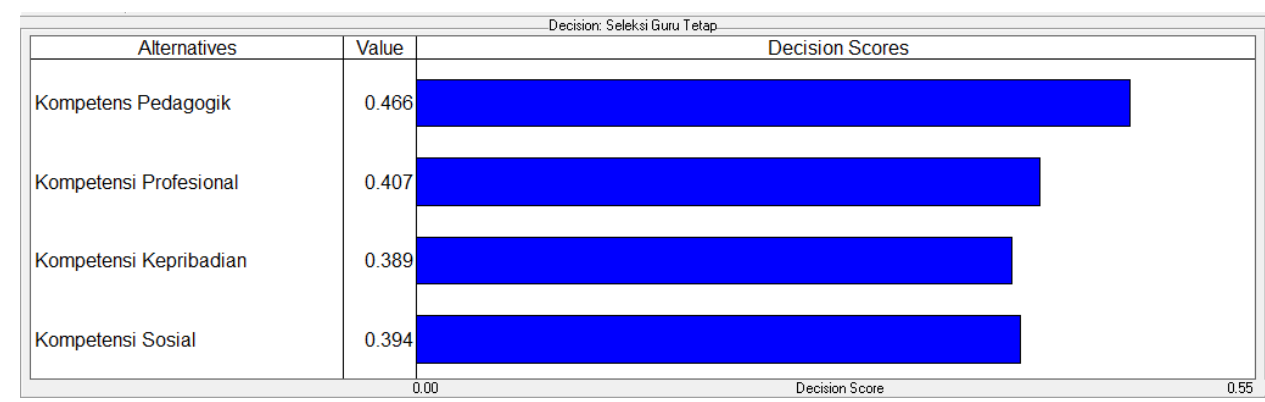

Gambar 6. Hasil Decision Score

\section{KESIMPULAN}

Atas dasar analisis dan pembahasan diatas maka dapat ditarik beberapa kesimpulan sebagai berikut:

1) Penentukan seleksi guru tetap SMK. XYZ dapat dibangun dengan pendekatan metode Fuzzy Infrence System mamdani dan AHP

2) Penentukan seleksi guru tetap dengan sistem pendukung keputusan dengan pendekatan metode fuzzy dan AHP lebih efektif, efisien, dan objektif dari pada penentuan seleksi guru secara manual.

3) Penentukan seleksi guru SMK. XYZ dengan pendekatan logika fuzzy menggunakan 14 kriteria dalam menentukan keputusan.

4) Dalam seleksi guru tetap dengan metode AHP, analisa yang dilakukan menggunakan metode proses analisa bertingkat dengan struktur hierarki 3 level. Hasil analisa, menunjukkan bahwa urutan alternatif Guru yang dapat dipertimbangkan adalah menunjukkan bahwa kriteria yang paling berpengaruh adalah Kompetensi Pedagogik, Kompetensi Profesional, Kompetensi Sosial, dan yang paling sedikit pengaruhnya adalah Kompetensi Kepribadian.

\section{DAFTAR PUSTAKA}

[1] Aruan, Antoni. 2014. "Sistem Pendukung Keputusan Pemilihan Asuransi Jiwa Menggunakan Metode Fuzzy Multi Criteria Decision Making”. Pelita Informatika Budi Darma VII. 3. 2014.

[2] Marimin, dan Nurul, (2010), Aplikasi Teknik Pengambilan Keputusan dalam Manajemen Rantai Pasok, IPB Press, Bogor.

[3] Efraim Turban, Jay E. Aronson, and Ting-Peng Liang. (2005). Decision Support System And Intelligent System-7th Ed. Pearson Education, New Jersey: Inc. Upper Saddle River.

[4] Kusumadewi, Sri, et al. (2006) Fuzzy Multi-Attribute Decision Making (Fuzzy MADM). Yogjakarta: Graha Ilmu.

[5] Eng, Agus Naba. (2009). Belajar Cepat Fuzzy Logic menggunakan Matlab. Yogyakarta: Andi Offset.

[6] Saaty, L. Thomas. (1993). Pengambilan Keputusan Bagi Para Pemimpin: Proses Hierarki Analitik Untuk Pengambilan Keputusan Dalam Situasi Yang Kompleks. Seri Manajemen No.134. Cetakan kedua. Jakarta: PT. Gramedia.

[7] Simarmata, Janner. (2010). Rekayasa Perangkat Lunak. Yogyakarta: Andi Offset. 